\title{
The Effect of ICT-Based Learning Media and Innovation Attitude to Learning Result Teaching With Hots
}

\author{
R Mursid ${ }^{1}$, S Sriadhi ${ }^{2}$, Harun Sitompul ${ }^{1}$ \\ \{mursid.tp@gmail.com, sriadhi@unimed.ac.id, profrunsit@yahoo.co.id\} \\ ${ }^{1}$ Educational Technology, Universitas Negeri Medan, Medan, Indonesia \\ ${ }^{2}$ Informatics Technology and Computer Education, Universitas Negeri Medan, Medan, Indonesia
}

\begin{abstract}
This study aims to determine whether the results of learning planning of teaching with HOTS is higher when taught by using online web and with offline computer, teaching planning with HOTS students is higher when having positive innovative attitude is higher than negative innovative attitude and to know the interaction between instructional media based on ICT with students' innovative attitude. This research is conducted on students who take course of purposive random sampling learning. The research method is quasi experiment with $2 \times 2$ factorial design. Statistical test used is descriptive statistic to present data and continued with inferential statistic by using two way ANOVA with significant level $\alpha=0,05$ followed by Scheffe test. The results of this study indicate that; (1) the learning result of teaching planning with online web-based learning media is higher than offline ICT; (2) Learning planning outcomes that have positive innovative attitudes are higher than negative innovative attitudes; and there is an interaction between ICT-based learning media with innovative attitudes toward learning planning outcomes.
\end{abstract}

Keywords: ICT-based learning media, innovation attitude, HOTS learning plan

\section{Introduction}

In the information age, the sophistication of information and communication technology has enabled the rapid exchange of information without being impeded by the boundaries of space and time (Dryden \& Voss, 1999). In contrast to the agrarian and industrial era, the advancement of a nation in the information / global era is highly dependent on the ability of its people to utilize knowledge to increase productivity. The characteristics of such a society are known as knowledge-based societies. People who master knowledge will be able to compete in the global era. Therefore, each country competes to integrate ICT in all aspects of national and state life, to build and cultivate a knowledge-based society in order to compete in a global era.

Dale (1969) explains that to ensure that learning resources used either or suited for the purposes described above must meet the following three conditions: (1) must be readily available; (2) should enable students to spur themselves; (3) must be individual, meet the needs of self-learning students. While the physical manifestations of hardware technology, software and learning materials according to Dale (1969) can be categorized in four types of technology namely printing technology, audio-visual technology, computer technology, and integrated technology.

Computer-based learning is a learning program by using computer software (learning CD) in the form of computer program that contains about learning content including: title, objectives, learning materials, and evaluation of learning. This is in line 
with what Heinich, Molenda, and James D. Russell (1985: 226) have stated that: "Computer systems can delivery instruction by allowing them to interact with the lesson programmed into the system; this is refered to computer based instruction ". Computer systems can deliver individual and direct learning to students by interacting with subjects programmed into computer systems, this is called computer-based learning media.

The World Wide Web is called a web or www, a multimedia that contains various information that can be accessed via the internet where hypermedia documents (computer files) are stored and can be retrieved through address that has been laid out and determined in a unique way. The Web is not just handling text-shaped material, but is capable of storing and retrieving hypermedia - a multimedia consisting of text, graphics, audio, and video. It further discloses that www is a collection of computers acting as a server that provides a variety of content servers, in which there are documents in certain formats that allow the document to be viewed as text, graphics, audio, and also related to documents on the web (McLeod and Schell, 2007: 71-72). In addition to being electronic and accessible anytime and anywhere and by anyone, according to Shelly (2007: 67) the web is also a service that is very much utilized in the internet because it consists of electronic documents from all countries. The Web provides innovative approaches in presenting training or distance learning. According to Hall (2003: 1), WBI (web-based instruction) is defined as a hypermedia-based learning program that utilizes various features and sources of www (world wide web) to create a supportive and meaningful learning environment. Meanwhile, according to Vaughan the world wide web is a distributed collaborative hypermedia information system. The system was designed as a protocol for connecting various document diversity housed on any computer on the Internet (Vaughan, 2006: 286). From the opinion of experts can be concluded, that is the web in this development research is a multimedia that contains various documents with various characters (text, audio,visual, animation) connected by the Internet network and can be accessed online.

Learning of teaching planning with web-based HOTS usually involves interactivity between learners and systems. To create an interactive learning system we can separate the design process into three elements or sections, namely information design, interaction design and presentation design (Kristof \& Satran, 1995)

The process of learning in the field of mechanical engineering education in the Learning Planning course with HOTS is seen from the learning completeness and student learning outcomes, there is no indication of significant problems like in the courses in educational cluster. However, in the learning process that took place in the class until now, still centered on lecturers or often called teacher centered or known by the traditional approach (Utami, et al: 2011). In connection with this, Thomas \& Litowitz (1986: 1) states that the main focus in all areas of education today is the impact of education on the ability of students in using HOTS. Understanding and upgrading the knowledge, cognitive abilities, and placements that guide, organize, and shape effective actions at work, family, and society are significant issues for the XXI century education. This shows that HOTS is a very important thing that must be applied and improved in college.Looking at the above description, it can be said that HOTS is an essential skill for successful study, work, and life in the information age and technology of the XXI century. HOTS and its components can be developed and used well when studying a knowledge. Therefore, the learning process in college should emphasize on the development of HOTS students. In this case, Lecturers need to ask 
students to use HOTS which includes applying, analyzing, evaluating and creating activities for learning activities through: discussion, fieldwork, practicum, and selfevaluating students that skill.

\section{Methods}

Population in this research is all students who take course of lesson planning on S1 program of mechanical engineering at T.A. 2016/2017. The sampling technique in this research is by using purposive sampling technique where this research is done on all population which is directly focused on target. The design of this study using an experimental approach that is a research that seeks to find and test the influence of a variable or more against other variables. This research is Quasi Experiment $2 \times 2$ factorial design. Through this design will be compared the influence of web learning media (online) and computer-based learning media (offline) to the learning outcomes of learning planning with HOTS in terms of innovative attitudes. Web-based learning media (online) and computer learning media (offline) is treated in a group of student experiments with innovative attitudes.

This analysis is done by technique of Anova factoria $2 \times 2$ with F test. Before the hypothesis is tested first, the requirement test for data collected is using normality test by using Liliefors test and homogeneity test by using $\mathrm{F}$ test and Bartlett test. Because the third hypothesis is significant, it means that there is interaction, then the research test is continued by using Scheffe test.

\section{Results And Discussion}

The results of this study are described in discussion below:

Table 1. Summary of Data Result of Descriptive Analysis Calculation.

\begin{tabular}{|c|c|c|c|c|c|}
\hline \multicolumn{6}{|c|}{ Innovative Attitudes } \\
\hline \multicolumn{2}{|l|}{ Learning Media } & Web (Online) A1) & $\begin{array}{l}\text { Computer } \\
\text { (A2) }\end{array}$ & (offline) & Total \\
\hline \multirow{5}{*}{ Positive (B1) } & $\mathrm{N} \sum X \sum X 2$ & 13 & 14 & & 27 \\
\hline & $\bar{X}$ & 387 & 348 & & 735 \\
\hline & $\mathrm{S}$ & 11572 & 10328 & & 21900 \\
\hline & & 42,32 & 26,52 & & 68,84 \\
\hline & & 2,9 & 2,56 & & 5,46 \\
\hline \multirow{5}{*}{ Negative(B2) } & $\mathrm{N} \sum X \sum X 2$ & 14 & 15 & & 29 \\
\hline & $\bar{X}$ & 294 & 321 & & 615 \\
\hline & $\mathrm{s}$ & 6759 & 7955 & & 14714 \\
\hline & & 29,32 & 25,53 & & 54,85 \\
\hline & & 3,43 & 2,57 & & 6 \\
\hline \multirow{5}{*}{ Total } & $\mathrm{N} \sum X \sum X 2$ & 27 & 29 & & 56 \\
\hline & $\bar{X}$ & 681 & 669 & & 1350 \\
\hline & $\mathrm{S}$ & 18331 & 18283 & & 36614 \\
\hline & & 71,64 & 52,05 & & 123,69 \\
\hline & & 6,33 & 5,13 & & 11,46 \\
\hline
\end{tabular}

Testing requirements data analysis performed on the test of normality and homogeneity. Next for hypothesis testing by using $2 \times 2$ factorial variance variance 
analysis technique, Scheffe test is needed to calculate the average price of each group presented learning data of learning planning with HOTS in Table 2.

Table 2. Summary of Anova Factorial 2x2.

\begin{tabular}{|c|c|c|c|c|c|}
\hline $\begin{array}{l}\text { Source } \\
\text { Varians }\end{array}$ & $\mathrm{dk}$ & JK & RJK & $\mathrm{F}_{\text {count }}$ & $\begin{array}{ll}\mathrm{F}_{\text {tabl }} & \mathrm{F}_{\text {table }} \\
& 0,01 \\
0,05 & \end{array}$ \\
\hline Inter Group (A) & 1 & 28,45 & 28,45 & 7,56 & $4,037,17$ \\
\hline In Group (B) & 1 & $\begin{array}{r}1214,5 \\
5\end{array}$ & $\begin{array}{r}1214,5 \\
5\end{array}$ & 5 & \\
\hline Interaction $(\mathrm{AxB})$ & 1 & $\begin{array}{r}1429,2 \\
6\end{array}$ & $\begin{array}{r}1429,2 \\
6 \\
\end{array}$ & 6 & \\
\hline Error & 52 & 294,5 & 6,57 & & \\
\hline Total & 55 & 2883,7 & & & \\
\hline
\end{tabular}

In connection with the existence of interaction it is necessary to do further test with Scheffe test. The Scheffe test is performed because the data for each cell is not the same, the test results using Scheffe test can be seen in Table 3.

Table 3. Summary of Test Results Using Scheffe Test.

\begin{tabular}{llll}
\hline Statistical Hypothesis & $\mathrm{F}_{\text {count }}$ & $\mathrm{F}_{\text {table }}$ & Description \\
\hline $\mathrm{H}_{0}: \mu \mathrm{A}_{1} \mathrm{~B}_{1=\mu \mathrm{A}_{2} \mathrm{~B}_{1}}$ & 7,22 & 3,70 & Significant \\
\hline $\mathrm{H}_{0}: \mu \mathrm{A}_{1} \mathrm{~B}_{1=\mu \mathrm{A}_{1} \mathrm{~B}_{2}}$ & 13,24 & 3,70 & Significant \\
\hline $\mathrm{H}_{0}: \mu \mathrm{A}_{1} \mathrm{~B}_{1=\mu \mathrm{A}_{2} \mathrm{~B}_{2}}$ & 12,91 & 3,70 & Significant \\
\hline $\mathrm{H}_{0}: \mu \mathrm{A}_{2} \mathrm{~B}_{1=\mu \mathrm{A}_{1} \mathrm{~B}_{2}}$ & 9,13 & 3,70 & Significant \\
\hline $\mathrm{H}_{0}: \mu \mathrm{A}_{2} \mathrm{~B}_{1=\mu \mathrm{A}_{2} \mathrm{~B}_{2}}$ & 10,66 & 3,70 & Significant \\
\hline $\mathrm{H}_{0}: \mu \mathrm{A}_{1} \mathrm{~B}_{2}=\mu \mathrm{A}_{2} \mathrm{~B}_{2}$ & $-1,50$ & 3,70 & Not Significant \\
\hline
\end{tabular}

Learning of teaching planning with HOTS of students who were taught by using online web-based learning media was higher than the result of the offline ICT learning of students who were taught by computer-based learning media, although the average learning outcomes among the two groups were not too different. Thus, the results of the study found in accordance with the opinion expressed by Mayer (2014) that learning media support learning activities, where the function or usefulness of the media, among others: (1) create concrete concepts abstract, (2) carrying objects that are dangerous or difficult to obtain into the learning environment, (3) displaying objects too large, (4) displaying objects that can not be observed with the naked eye, (5) observing movements too fast, (6) enabling students to interact directly with their environment, (7) the freshness of observation and perception for the observation of student learning, (8) generating learning motivation, (9) presenting information learning consistently and can be repeated or stored according to need, (10) presenting messages or learning information simultaneously, limiting time and space constraints, and (11) control the direction and speed of student learning. Selection of appropriate media in learning will make students more understanding and deepen the content of learning materials and play an active role to find and dig material so as to improve student learning outcomes. 
The findings of this research are also supported by previous research conducted by Putra (2008) on MTs students which shows that the use of computer-based interactive media is more effective in improving students' knowledge and understanding than using conventional media on teaching planning subjects with HOTS. And also the results showed that the average learning outcomes of teaching planning with HOTS students who have positive innovative attitude more positive than the results of teaching planning learning with HOTS students who have negative innovative attitude.

Students who have a positive innovative attitude will be able to create and identify problem-solving alternatives, imaginative, able to do things smoothly in expressing their ideas. Students can easily adapt, adjust what is known to what they will learn in the completion of presentation making using Ms. software. Office Powerpoint 2010 after following the learning using computer-based learning media that has been given by lecturers. because innovative attitudes are able to solve problems from abstract symptoms to reality. Because the innovative attitude is able to solve the problems of abstract symptoms to its utterity.

With all the capabilities it has, students who have positive innovative attitudes will easily reach the basic competencies in the lesson planning lesson with HOTS compared to students who have negative innovative attitudes.

Thus, the results of the study are found in accordance with the opinions expressed by Hagen (Irawati, 2003) that the qualities that give rise to creativity will result in an innovative personality. Innovative personalities are: (1) open to new experiences; (2) creative imagination; (3) awareness and responsibility to succeed; and (4) have a perception that the world has challenges. Individual response to change is a decision on innovation, whether the individual accepts or rejects the innovation.

The findings of this researcher is also supported by previous research conducted by Karitimi (2004) in junior high school students who have various positive, moderate and negative skills using computer-based learning media proven to improve the mastery of concept, creative thinking skill and science process skill of junior high school students.

According to Djaali (2007) attitude learning participate determine the intensity of learning activities. A positive attitude of learning leads to a higher intensity of activity than a negative learning attitude. The role of attitude in this case not only determine what someone sees, how also he saw it. Based on what has been proposed a positive attitude of learning is closely related to interest and motivation. Students who have a positive attitude will be more active in learning and thus will get better results compared to students whose learning attitude is negative. Thus, the learning result of teaching planning with HOTS students with online web-based learning media will be more easily understood by students who have positive innovative attitude, this is in accordance with the characteristics of students who have positive innovative attitude tend to more easily follow the new way of learning.

According to Rusman, et al (2011: 99-100), the advantage of computer-based learning is the application of the principle of thorough learning or mastery learning. In the implementation of computer-based learning all students must be able to complete all the learning experiences are packed in computer-based learning program, whether it is the understanding of the material and the task of doing tests or evaluations that must be completed correctly. If the student is wrong in doing the exercises, the computer will give feedback, that the wrong answer, so the student must return to the description of the material that has not been understood, after that the student can return to the 
exercise problem was to be done correctly. Thus, students who have positive innovative ability will quickly complete in learning the content / subject matter programmed in computer-based learning. But those who have a negative innovative attitude will have difficulty in working on or understanding the existing content.

\section{Conclusions}

Based on the results of research and discussion previously mentioned, it can be concluded that: (1) the results of learning planning of teaching with HOTS students who are taught by using online web-based learning media is higher than the results of off-line ICT learning; (2) learning outcomes of teaching planning with HOTS students with positive innovative attitudes are higher than those having negative innovative attitudes; and (3) there is interaction between ICT-based learning media in learning with student's innovative attitude toward teaching learning result with HOTS, it means that students who have positive innovative attitude by using online and web-based learning media and offline computer will have learning learning planning result HOTS is higher than students with negative innovative attitudes.

\section{References}

[1] Dale, E. (1969). Audiovisual Method in Teaching. New York: Dyden Press.

[2] Hall, R.H. (2012). Usabiliti Assessment of a Web-Based Learning System for Teaching Web Development: A Progress Scaffolding Approach, 2003. http://www.umr.edu. Accessed 11 Agustus 2017.

[3] Heinich, R., Molenda, M., Russell, J. D., \& Smaldino, S.E. (2002). Instructional Media and Technology for Learning, 7th edition. New Jersey: Prentice Hall, Inc.

[4] Heinich, R., Molenda, M., Russell, J. D., \& Smaldino, S.E. (2002). Instructional Media and Technology for Learning, 7th edition. New Jersey: Prentice Hall, Inc.

[5] Joyce, B., dan Weil, M., (2009). Models of Teaching. Yogyakarta: Pustaka Pelajar.

[6] Mayer, R. E. (2014). Multimedia Learning. (2ndEd.). New York: Cambridge University Press

[7] Riduwan. (2007). Metode dan Teknik Menyusun Proposal Penelitian. Bandung: ALFABETA.

[8] Rusman. (2011). Pembelajaran Berbasis Teknologi Informasi dan Komunikasi: Mengembangkan Profesionalisme Guru. Jakarta: PT Raja Grafindo Persada.

[9] Sardiman. (2010). Interaksi dan Motivasi Belajar Mengajar. Jakarta: Penerbit Grafindo.

[10] Shelly. (2007). Discovering Computers. Jakarta: Salemba Infotek.

[11] Utami, B., et al. (2011). Penerapan Pendekatan Konstruktivisme Melalui Model Pembelajaran Think Pair Share (TPS) dalam Kegiatan Lesson Study untuk Meningkatkan Kualitas Proses dan Hasil Belajar Strategi Belajar-Mengajar. Jurnal Inovasi Pendidikan Jilid 12 Nomor 1 p 1 -18. 